Проведено дослідження можливості застосування малопоширених пряносмакових рослин під час виготовлення хліба пшеничного. Експериментально обтрунтовано та впроваджено заміну частини рецептурної кількості борошна на висушені і розмелені ефіроносні, технічні, пряно-смакові та овочеві рослини під час виготовлення хліба. За визначеними фізико-хімічними, органолептичними показниками хліба підтверджено можливість виготовлення хліба з додаванням рослин

Ключові слова: пікнантемум тонколистий, лобода квіноя, монарда двійчаста, агастахіс зморикуватий, вітекс коноплеподібний, ельшольція Стаунтона, м'ята колоскова Мароканська, нові рецептури, хлібні вироби

$\square \longrightarrow \square$

Проведено исследование возможности применения редких пряновкусовых растений при изготовлении хлебапшеничного.Экспериментально обоснована и внедрена замена части рецептурного количества муки на высушенные и размолотые эфироносные, технические, пряно-вкусовые и овощные растения при изготовлении хлеба. По определенным физико-химическим, органолептическим показателям хлеба подтверждена возможность изготовления хлеба с добавлением растений

Ключевые слова: пикнантемум тонколистый, лебеда квиноа, монарда двойчастая, агастахис морщинистый, витекс коноплеподобный, ельшольция Стаунтона, мята колосковая Марокканская, новые рецептуры, хлебные изделия

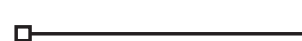

UDC 664.665

DOI: $10.15587 / 1729-4061.2017 .108900$

\section{SUBSTANTIATION OF THE USE OF SPICE PLANTS FOR ENRICHMENT OF WHEAT BREAD}

N. Osokina

Doctor of Agricultural Sciences, Professor*

E-mail: ninaosokina1953@gmail.com

K. Kostetska

$\mathrm{PhD}$, Associate Professor*

E-mail: kostetskakateryna@gmail.com

O. Ger a s y m c h u k

$\mathrm{PhD}$, Associate Professor*

E-mail: elena.gerasim4uk@ukr.net

V. Vozian

Lecturer*

E-mail: voziian07@gmail.com

L. T e le z h e n k o

Doctor of Technical Sciences, Professor

Department of restaurant and health promoting catering

Odessa National Academy of Food Technologies

Kanatna str., 112, Odessa,Ukraine, 65039

E-mail: telegenko@ukr.net

O. Pris s

Doctor of Technical Sciences, Associate Professor**

E-mail: olesyapriss@gmail.com

V. Z h u k ova

$\mathrm{PhD}$, Assistant**

V. Verkholantseva PhD, Senior Lecturer*** E-mail: milaeva.v@mail.ru

N. Pal y a n i c h k a

PhD, Associate Professor***

E-mail. palyanichkan@gmail.com

D. S t e pan e n k o

$\mathrm{PhD}$, Associate Professor

Department of Ecology and Zoology

Bogdan Khmelnitsky Melitopol State Pedagogical University

Hetmanska str., 20, Melitopol, Ukraine, 72312

*Department of technology of storage and processing of grain Uman National University of Horticulture Institutska str., 1, Uman, Ukraine, 20305

**Department of Technology of Processing and

Storage of Agricultural Products $* \star \star *$

$\star * \star$ Department of processing and food production equipment named after professor F. Yalpachik $* * * *$

$\star \star \star *$ Tavria State Agrotechnological University

B. Khmelnitsky ave., 18, Melitopol, Ukraine, 72310

\section{Introduction}

Selection of wheat varieties with certain technological characteristics provides high-quality bakery products [1]. Spice, aromatic, volatile-oil-bearing plants are rich in essential aromatic oils, vitamins, minerals that impart phytoncidic, prophylactic, therapeutic, functional properties to products, improve food taste, and enhance digestion [2, 3]. Since there is little data on the application of such plants of Ukrainian origin in bread making, it is important to deepen 
and broaden the research in order to scientifically substantiate the ways and methods of their rational use, study the potential of spice plants as raw materials, and expand the range of bakery products [4]. The favorable proportion of the components of the chemical composition of the latter makes it possible to produce new types of functional products [5].

In order to develop an effective technology for the use of plant additives, create new types of products with the properties that meet today's needs of consumers in Ukraine and the world, it is necessary to clarify the relationship between the components of spice plants and other components [1].

\section{Literature review and problem statement}

Wheat production should account for about a half of the total grain production in Ukraine [6]. It is proposed to draw special attention to the increase in the yield and quality of valuable wheat varieties to produce high-quality bread, pasta, and groats [7].

Phytonutrients should be used when developing bakery products for special purposes: enriched, dietary, therapeutic, child nutrition, with immunomodulatory, antioxidant, radioprotective, tonic and other physiological properties [8].

Spice herbs with antioxidant and antibacterial properties can be viewed as a means to stabilize the properties of longterm storage products, such as dried crusts, toast, to prevent microbial, oxidative damage $[9,10]$.

An important positive result of using spice herbs is also revealed in bread baking [11]. It is important to reduce the chemical load on the human body for solving the pressing problems of the industry [12].

In bread making, it is necessary to reduce or exclude the use of enhancers and other food additives [13].

Wheat bread contains the nutrients necessary for humans [14]. Bread contains proteins, carbohydrates, vitamins B, PP, mineral compounds, for example, vital salts of calcium, iron, phosphorus [15]. Bakery products are high in calories, $100 \mathrm{~g}$ of wheat bread contains 245-255 kcal [16]. In Ukraine, the issue of producing competitive products that could be sold in European countries and would comply with generally accepted standards is gaining popularity [17].

Although the existing range of bread is quite diverse, it is necessary to carry out extensive work to expand and improve the range of bakery products, create new dietary and therapeutic varieties of bread. Improvement of product quality, development of the range of products, including those for dietary purposes, development of technological regimes of their preparation, is an urgent problem for the baking industry [18].

Addition of spice herbs is expected to improve consumer properties of food, which will also affect the chemical composition, nutrient digestibility, energy value, biological and organoleptic characteristics [19, 20].

Since there is little data on the application of such plants of Ukrainian origin in bread making, it is important to deepen and broaden the research in order to scientifically substantiate the ways and methods of their rational use, study the potential of spice plants as raw materials, develop optimum technological modes of proofing and baking of bread of new formulations and expand the range of bakery products. The favorable proportion of the components of the chemical composition of the latter will make it possible to produce new types of functional products.
So, the issue of developing new types of food products by improving existing formulations remains relevant and requires immediate resolution through additional research.

\section{The aim and objectives of the study}

The research was aimed at determining the technological suitability of the grain of wheat variety Smuglyanka for flour and bread production and the use of rare volatile-oil-bearing, technical, spice and vegetable plants for bread making. This will expand the range of bakery products.

To achieve this aim, the following objectives were accomplished:

- to investigate technological parameters of flour of wheat variety Smuglyanka;

- to determine physicochemical, organoleptic parameters of bread;

- to determine the optimum prescription dosage of plant components in the production of bread of new formulations.

\section{Materials and methods for studying the quality of flour and bread of new formulations and physicochemical, organoleptic parameters}

4.1. Research materials and equipment used in the experiment

Grain of soft spring wheat of variety Smuglyanka, used in the study, was grown on the pilot field of the farm "Bodnyuk" in Graniv village, Haysin district, Vinnytsia region.

The plants used for bread making: Narrowleaf Mountainmint (Piknanthemum trifolium L.), Quinoa (Chenopōdium quīnoa L.), Scarlet Beebalm (Monarda didyma L.), Korean Mint (Agastache rugosa L.), Hemp Dogbane (Vitex cannabinum L.), Mint-shrub (Elsholtzia Stauntonii L.), Moroccan Spearmint (Mentha spicata Moroccan L.).

The plants are grown in the northern part of the RightBank Forest-Steppe of Ukraine on the fields of the laboratory of medical botany of the M. M. Hryshko National Botanic Garden of NAS of Ukraine.

The materials and methods for studying the quality of flour and bread of new formulations and physicochemical, organoleptic parameters are described in more detail in [1].

\section{Results of studying the quality indicators of} flour and bread

Organoleptic and baking indicators of flour from wheat variety Smuglyanka are given in Table 1.

According to the evaluation of wheat flour (on the example of high-grade flour) in comparison with the standards, compliance of organoleptic properties (color, smell, taste) to the norms [7] for the high-grade flour is determined. The investigated flour has a smell and taste peculiar to wheat flour, without foreign smells and flavors. There is no crunch when chewing the flour.

Table 1shows that grain of wheat variety Smuglyanka has stable high bakery properties.

Thus, the gluten content in flour from wheat variety Smuglyanka corresponds to the gluten content of the highgrade flour and is $26 \%$, which is $2 \%$ higher than the lower limit of the standard. 
Table 1

Quality indicators of flour from wheat variety Smuglyanka

\begin{tabular}{|c|c|c|c|c|}
\hline \multicolumn{2}{|c|}{ Indicator } & $\begin{array}{c}\text { Allowable rate } \\
(\text { DSTU ISO 46.004-99)* [7] }\end{array}$ & Actual quality & $\begin{array}{l}\text { Conclusion on } \\
\text { compliance }\end{array}$ \\
\hline \multicolumn{2}{|c|}{ Color } & $\begin{array}{l}\text { white, white with a yellowish shade/"'"/ } \\
\text { white with a yellow or gray shade }\end{array}$ & white & Complies \\
\hline \multicolumn{2}{|c|}{ Smell } & $\begin{array}{l}\text { peculiar to wheat flour, without } \\
\text { foreign smells, not fusty, not musty. }\end{array}$ & $\begin{array}{l}\text { peculiar to wheat flour, without foreign } \\
\text { smells, not fusty, not musty. }\end{array}$ & Complies \\
\hline \multicolumn{2}{|c|}{ Taste } & $\begin{array}{l}\text { peculiar to wheat flour, without foreign } \\
\text { flavors, not sour, not bitter. There } \\
\text { should not be crunch when chewing }\end{array}$ & $\begin{array}{l}\text { peculiar to wheat flour, without foreign } \\
\text { flavors, not sour, not bitter. There } \\
\text { should not be crunch when chewing }\end{array}$ & Complies \\
\hline \multicolumn{2}{|c|}{ Humidity, $\%$, up to } & 15 & 11.0 & Complies \\
\hline \multicolumn{2}{|c|}{ Amount of raw gluten, $\%$} & at least $24.0 / 25.0 / 21.0$ & 26.0 & high grade \\
\hline \multirow[b]{2}{*}{ Gluten quality } & group & I-II/I-II/I-II & II & \multirow[b]{2}{*}{ Complies } \\
\hline & $\begin{array}{l}\text { units of } \\
\text { the IDK device }\end{array}$ & $45-100$ & 82 & \\
\hline \multicolumn{2}{|c|}{ Whiteness, c. u. of the Skyb-M device } & at least $54 / 36-53 / 12-35$ & 58 & high grade \\
\hline \multicolumn{2}{|c|}{ Acidity, deg. } & up to $3.0 / 3.5 / 4.5$ & 2.2 & high grade \\
\hline \multicolumn{2}{|c|}{ Falling number, s, at least } & 160 & 442 & Complies \\
\hline
\end{tabular}

Note: * - up to the dash - high grade; after the dash - 1st/2nd grades

The readings of the IDK device in terms of gluten quality of flour from the wheat of the specified grade (82 units) correspond to the quality group II and are characterized as satisfactory weak gluten.

It was found that the falling number for flour from wheat variety Smuglyanka is $442 \mathrm{~s}$, which is almost 3 times more than the established requirements.

In the sample of flour from wheat variety Smuglyanka, the value of acidity corresponds to the high-grade flour $\left(2.2^{\circ}\right)$.

Taking into account the readings of the Skyb-M device (58 units), the studied flour was attributed to a high grade.

So, all quality indices of flour from wheat variety Smuglyanka are in acceptable limits and correspond to the optimum level for obtaining high-quality bread.

A good water absorption capacity of flour was noted, the dough was quickly kneaded (2 min), had a good consistency for about $1 \mathrm{~min}$, after which it actively fermented.

To prepare the plant powder, an overground green part of the plants, which has been dried, ground in a laboratory mill to a particle size of $10^{-4}-10^{-1} \mathrm{~mm}$, and mixed to take a weighed prescription sample was used. To prepare the flour of Quinoa, seeds of Quinoa, which have been ground in a laboratory mill to a particle size of 30-40 microns and mixed for taking a weighed prescription sample were used.

Photos of the bread are shown in Fig. 1-3.

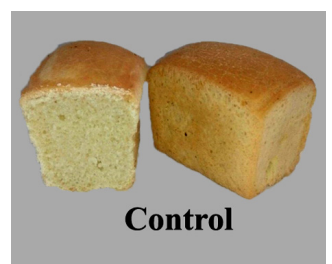

Fig. 1. Photo of bread made of flour from wheat variety Smuglyanka (control)
According to organoleptic parameters, wheat bread (control) complies with the established requirements: the surface smooth, without large cracks and blows; the crumb - elastic, quickly restores the original shape, well-baked, not moist, not sticky, with the developed uniform porosity, without hardening; the color of the crumb - white; taste and smell - corresponds to the name of bread, without foreign taste and smell.

The quality of bread of new formulations is somewhat different from that of control samples: the color of the crumb - light and dark yellow, brown, greenish (Fig. 2, 3); taste and smell - peculiar to the added plants.
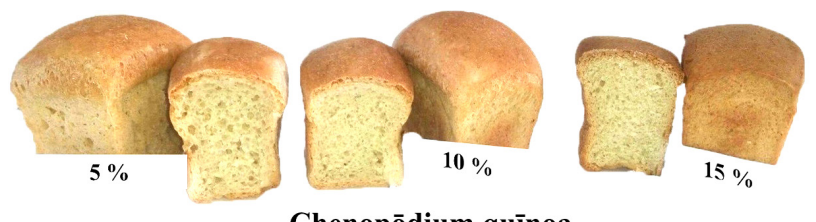

Chenopōdium quīnoa

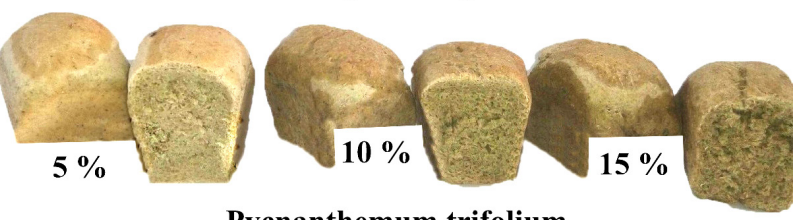

Pycnanthemum trifolium

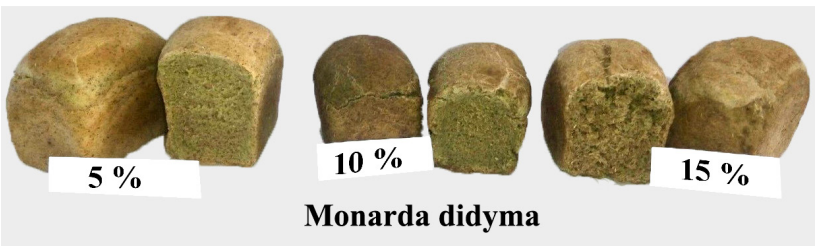

Fig. 2. Photo of bread with the addition of 5,10 and $15 \%$ of flour from Quinoa (lat. Chenopōdium quīnoa L.) seeds and powder of Narrowleaf Mountainmint (lat. Pycnanthemum trifolium L.) and Scarlet Beebalm (lat. Monarda didyma L.) 
The powder of the plants contained anthocyanic pigments and had a pronounced color. The expediency of introducing up to $5 \%$ of Scarlet Beebalm powder; up to $10 \%$ of the air-dry raw material of Narrowleaf Mountainmint and up to $10 \%$ of the flour of Quinoa grain into wheat dough was revealed. Such bread had a uniformly colored (light yellow, greenish, dark brown) crust without blows and cracks, elastic crumb, thin-walled porosity, pronounced bread taste and a pleasant aroma of additives.

The results of physicochemical analysis of bread from flour, obtained from wheat variety Smuglyanka of different formulations are shown in Table 2.

Table 3 shows the organoleptic quality characteristics of bread from wheat flour and new formulations.

Table 4 shows the organoleptic quality indicators of bread with the addition of powder of Narrowleaf Mountainmint, Mint-shrub, Hemp Dogbane, Moroccan Spearmint.

The bread of flour from wheat variety Smuglyanka (control) (Fig. 1, Table 3) and with the addition of up to $5 \%$ of flour from Quinoa grain (Fig. 2, Table 3) is estimated to be excellent ( 4.8 and 4.6 points). Whereas, good (4.0-4.2 points) - bread with the addition of up to $5 \%$ of Scarlet Beebalm, up to $10 \%$ of powder of air-dry raw material of Narrowleaf Mountainmint and $10 \%$ of flour from Quinoa grain (Fig. 2, Table 3). For the remaining samples (Fig. 3, Table 4), a satisfactory overall baking score (3.0-3.7 points) was determined.

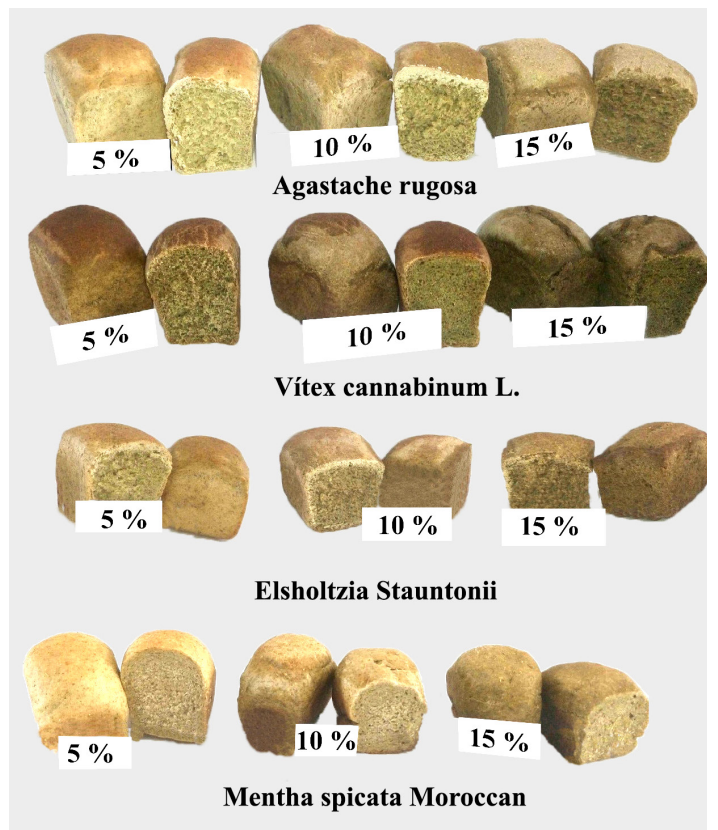

Fig. 3. Photo of bread with the addition of 5, 10 and $15 \%$ of powder of Korean Mint (lat. Agastache rugosa L.), Hemp Dogbane (lat. Vitex cannabinum L.), Mint-shrub (lat. Elsholtzia Stauntonii L.), Moroccan Spearmint (lat. Mentha spicata Moroccan L.)

Physicochemical quality indicators of bread from flour of wheat variety Smuglyanka (control) and new formulations

\begin{tabular}{|c|c|c|c|c|c|c|c|}
\hline \multicolumn{2}{|c|}{$\begin{array}{c}\text { Wheat bread } \\
\text { (grain of wheat variety Smuglyanka) }\end{array}$} & Weight, g & Humidity, \% & Crumb acidity, deg. & Porosity, \% & Volume, $\mathrm{cm}^{3}$ & Specific volume, $\mathrm{cm}^{3} / \mathrm{g}$ \\
\hline \multicolumn{2}{|c|}{ Control } & 32.6 & 45.3 & 2.0 & 66.3 & 3.02 & 0.092 \\
\hline \multirow{3}{*}{ Korean Mint } & $5 \%$ & 33.7 & 45.6 & 2.6 & 66.2 & 2.99 & 0.089 \\
\hline & $10 \%$ & 33.2 & 45.9 & 2.9 & 66.1 & 2.87 & 0.086 \\
\hline & $15 \%$ & 33.2 & 46.0 & 3.0 & 66.0 & 2.77 & 0.083 \\
\hline \multirow{3}{*}{$\begin{array}{c}\text { Narrowleaf } \\
\text { Mountainmint }\end{array}$} & $5 \%$ & 34.1 & 46.2 & 2.7 & 66.3 & 2.92 & 0.086 \\
\hline & $10 \%$ & 33.7 & 46.8 & 2.7 & 66.1 & 2.80 & 0.083 \\
\hline & $15 \%$ & 33.4 & 48.3 & 3.4 & 66.0 & 2.67 & 0.080 \\
\hline \multirow{3}{*}{$\begin{array}{l}\text { Moroccan } \\
\text { Spearmint }\end{array}$} & $5 \%$ & 33.7 & 47.5 & 2.9 & 60.0 & 2.64 & 0.078 \\
\hline & $10 \%$ & 33.1 & 48.0 & 3.8 & 56.2 & 2.44 & 0.074 \\
\hline & $15 \%$ & 32.2 & 49.9 & 3.9 & 56.2 & 2.38 & 0.074 \\
\hline \multirow{3}{*}{ Mint-shrub } & $5 \%$ & 33.7 & 46.6 & 2.8 & 65.2 & 2.88 & 0.085 \\
\hline & $10 \%$ & 33.3 & 47.0 & 3.9 & 64.3 & 2.82 & 0.085 \\
\hline & $15 \%$ & 33.2 & 48.1 & 3.9 & 64.2 & 2.80 & 0.084 \\
\hline \multirow{3}{*}{ Scarlet Beebalm } & $5 \%$ & 33.6 & 45.6 & 2.6 & 66.2 & 2.65 & 0.079 \\
\hline & $10 \%$ & 33.5 & 45.8 & 2.9 & 64.7 & 2.48 & 0.074 \\
\hline & $15 \%$ & 33.1 & 45.9 & 3.0 & 59.5 & 2.45 & 0.074 \\
\hline \multirow{3}{*}{ Hemp Dogbane } & $5 \%$ & 33.9 & 45.9 & 2.4 & 62.9 & 2.51 & 0.074 \\
\hline & $10 \%$ & 33.7 & 46.8 & 2.7 & 59.2 & 2.43 & 0.072 \\
\hline & $15 \%$ & 33.7 & 47.2 & 2.9 & 59.1 & 2.43 & 0.072 \\
\hline \multirow{3}{*}{ Quinoa } & $5 \%$ & 34.9 & 45.6 & 2.2 & 70.3 & 3.36 & 0.096 \\
\hline & $10 \%$ & 34.0 & 45.8 & 2.3 & 69.9 & 3.25 & 0.096 \\
\hline & $15 \%$ & 33.7 & 45.9 & 2.6 & 69.7 & 3.21 & 0.095 \\
\hline \multicolumn{2}{|c|}{$H I P_{05}$} & 1.69 & 2.34 & 0.15 & 3.28 & 0.15 & 0.001 \\
\hline
\end{tabular}


Table 3

Organoleptic quality indicators of bread from flour of wheat variety Smuglyanka (control) and with the addition of flour from Quinoa seeds and powders of Narrowleaf Mountainmint and Scarlet Beebalm

\begin{tabular}{|c|c|c|c|c|c|c|c|}
\hline \multicolumn{2}{|c|}{$\begin{array}{c}\text { Wheat bread (grain of } \\
\text { wheat variety Smuglyanka) }\end{array}$} & Crust color & Appearance & Crumb color & Smell & Taste & Points \\
\hline \multicolumn{2}{|l|}{ Control } & yellow & $\begin{array}{l}\text { smooth crust, without contami- } \\
\text { nation, large cracks and blows }\end{array}$ & white & bread & $\begin{array}{l}\text { normal, peculiar to } \\
\text { bread }\end{array}$ & 4.8 \\
\hline \multirow{3}{*}{ Quinoa } & $5 \%$ & yellow & $\begin{array}{l}\text { smooth crust, without contami- } \\
\text { nation, large cracks and blows }\end{array}$ & yellow & spicy, nutty & peculiar to bread & 4.6 \\
\hline & $10 \%$ & yellow & $\begin{array}{l}\text { smooth crust, without contami- } \\
\text { nation, large cracks and blows }\end{array}$ & yellow & spicy, nutty & $\begin{array}{c}\text { peculiar to bread with } \\
\text { a smack of additive }\end{array}$ & 4.1 \\
\hline & $15 \%$ & yellow & $\begin{array}{l}\text { smooth crust, without contami- } \\
\text { nation, large cracks and blows }\end{array}$ & yellow & spicy, nutty & bitter & 3.2 \\
\hline \multirow{3}{*}{$\begin{array}{l}\text { Narrowleaf Moun- } \\
\text { tainmint }\end{array}$} & $5 \%$ & gray-brown & $\begin{array}{l}\text { smooth crust, without contami- } \\
\text { nation, large cracks and blows }\end{array}$ & light-brown & honey, weak & $\begin{array}{c}\text { peculiar to bread with } \\
\text { a smack of additive } \\
\text { and honey }\end{array}$ & 4.2 \\
\hline & $10 \%$ & brown & $\begin{array}{l}\text { smooth crust, without contami- } \\
\text { nation, large cracks and blows }\end{array}$ & $\begin{array}{c}\text { brown with a } \\
\text { greenish shade }\end{array}$ & honey & $\begin{array}{c}\text { peculiar to bread with } \\
\text { a smack of additive }\end{array}$ & 4.0 \\
\hline & $15 \%$ & greenish & $\begin{array}{l}\text { smooth crust, without contami- } \\
\text { nation, large cracks and blows }\end{array}$ & \begin{tabular}{|c|} 
dark-brown \\
with a greenish \\
shade
\end{tabular} & honey & bitter & 3.7 \\
\hline \multirow{3}{*}{ Scarlet Beebalm } & $5 \%$ & light-brown & $\begin{array}{l}\text { smooth crust, without contami- } \\
\text { nation, large cracks and blows }\end{array}$ & light-brown & additive & $\begin{array}{c}\text { peculiar to bread with } \\
\text { a smack of additive }\end{array}$ & 4.0 \\
\hline & $10 \%$ & dark-brown & $\begin{array}{l}\text { smooth crust, without contami- } \\
\text { nation, large cracks and blows }\end{array}$ & $\begin{array}{l}\text { brown with a } \\
\text { greenish shade }\end{array}$ & additive & bitter & 3.1 \\
\hline & $15 \%$ & dark-brown & $\begin{array}{l}\text { smooth crust, without contami- } \\
\text { nation, large cracks and blows }\end{array}$ & \begin{tabular}{|} 
brown with a \\
greenish shade
\end{tabular} & additive & bitter & 3.0 \\
\hline
\end{tabular}

Table 4

Organoleptic quality indicators of bread with the addition of powder of Korean Mint, Mint-shrub, Hemp Dogbane, Moroccan Spearmint

\begin{tabular}{|c|c|c|c|c|c|c|c|}
\hline \multicolumn{2}{|c|}{$\begin{array}{c}\text { Wheat bread (grain of } \\
\text { wheat variety Smuglyanka) }\end{array}$} & \multirow{2}{*}{\begin{tabular}{l|} 
Crust color \\
light-brown
\end{tabular}} & \multirow{2}{*}{$\begin{array}{c}\text { Appearance } \\
\text { smooth crust, without contamina- } \\
\text { tion, large cracks and blows }\end{array}$} & \multirow{2}{*}{$\begin{array}{c}\text { Crumb color } \\
\text { light-brown }\end{array}$} & \multirow{2}{*}{\begin{tabular}{c|} 
Smell \\
additive
\end{tabular}} & \multirow{2}{*}{$\begin{array}{l}\text { Taste } \\
\text { bitter }\end{array}$} & \multirow{2}{*}{$\begin{array}{c}\text { Points } \\
3.1\end{array}$} \\
\hline \multirow{3}{*}{ Korean Mint } & $5 \%$ & & & & & & \\
\hline & $10 \%$ & brown & $\begin{array}{l}\text { smooth crust, without contamina- } \\
\text { tion, large cracks and blows }\end{array}$ & brown & additive & bitter & 3.0 \\
\hline & $15 \%$ & brown & $\begin{array}{l}\text { smooth crust, without contamina- } \\
\text { tion, with some cracks and blows }\end{array}$ & brown & additive & bitter & 3.0 \\
\hline \multirow{3}{*}{ Mint-shrub } & $5 \%$ & light-brown & $\begin{array}{l}\text { smooth crust, without contamina- } \\
\text { tion, large cracks and blows }\end{array}$ & light-brown & additive & $\begin{array}{c}\text { peculiar to bread with } \\
\text { a bitter smack }\end{array}$ & 3.7 \\
\hline & $10 \%$ & brown & $\begin{array}{l}\text { smooth crust, without contamina- } \\
\text { tion, with some cracks and blows }\end{array}$ & $\begin{array}{l}\text { dark-brown with } \\
\text { a greenish shade }\end{array}$ & additive & $\begin{array}{c}\text { peculiar to bread with } \\
\text { a bitter smack }\end{array}$ & 3.5 \\
\hline & $15 \%$ & dark-brown & $\begin{array}{l}\text { smooth crust, without contamina- } \\
\text { tion, with some cracks and blows }\end{array}$ & $\begin{array}{l}\text { dark-brown with } \\
\text { a greenish shade }\end{array}$ & additive & bitter & 3.3 \\
\hline \multirow{3}{*}{ Hemp Dogbane } & $5 \%$ & dark-brown & $\begin{array}{l}\text { smooth crust, without contamina- } \\
\text { tion, large cracks and blows }\end{array}$ & brown & additive & bitter & 3.2 \\
\hline & $10 \%$ & dark-brown & $\begin{array}{l}\text { smooth crust, without contamina- } \\
\text { tion, large cracks and blows }\end{array}$ & brown & additive & bitter & 3.0 \\
\hline & $15 \%$ & dark-brown & $\begin{array}{c}\text { smooth crust, without contamina- } \\
\text { tion, large cracks and blows }\end{array}$ & brown & additive & bitter & 3.0 \\
\hline \multirow{3}{*}{$\begin{array}{l}\text { Moroccan Spear- } \\
\text { mint }\end{array}$} & $5 \%$ & light-brown & $\begin{array}{l}\text { smooth crust, without contamina- } \\
\text { tion, large cracks and blows }\end{array}$ & light-brown & $\operatorname{mint}$ & $\begin{array}{c}\text { peculiar to bread with } \\
\text { a smack of mint }\end{array}$ & 3.7 \\
\hline & $10 \%$ & brown & $\begin{array}{l}\text { smooth crust, without contamina- } \\
\text { tion, with some cracks and blows }\end{array}$ & $\begin{array}{l}\text { brown with a } \\
\text { greenish shade }\end{array}$ & $\operatorname{mint}$ & $\begin{array}{c}\text { peculiar to bread with } \\
\text { a smack of mint }\end{array}$ & 3.6 \\
\hline & $15 \%$ & brown & $\begin{array}{l}\text { smooth crust, without contamina- } \\
\text { tion, with some cracks and blows }\end{array}$ & $\begin{array}{l}\text { brown with a } \\
\text { greenish shade }\end{array}$ & mint & $\begin{array}{l}\text { bitter with a smack } \\
\text { of mint }\end{array}$ & 3.5 \\
\hline
\end{tabular}




\section{Discussion of the results of studying the quality indicators of bread with enriching additives}

The obtained data demonstrate that the use of additives intensifies the dough fermentation process. Obviously, this is due to the introduction of sugars, macro-, microelements, organic acids to flour semi-finished products with plants. These substances are a nutrient medium, involved in the biosynthesis of the components of cellular metabolism and perform various functions in the metabolism of yeast cells.

When using spice plants Narrowleaf Mountainmint, Quinoa, Scarlet Beebalm, Korean Mint, Hemp Dogbane, Mint-shrub, Moroccan Spearmint, the porosity, volume and specific volume of the products were lower than those of the control sample by $15 \%, 20 \%$ and $22 \%$, respectively. An exception was the sample with the addition of Quinoa powder. The indicated physical indicators were higher than those of the control sample by $6 \%, 10 \%$ and $4 \%$, respectively.

In the new samples of bread, in the crumb there were visible particles of the enriching additive, the presence of which during the preparation of dough, obviously, negatively affected the structure and properties of the gluten frame of the dough.

In the studied samples, an increase in acidity by $9-49 \%$ compared with control samples was identified. The more intense acid accumulation in the test samples of the dough is due to the presence of organic acids in this plant material. This may be due to the intensification of lactic acid fermentation, that is, to be the evidence of creation of more favorable conditions for lactic acid bacteria.

The replacement of a part of the prescription amount of flour with dried and milled plants Narrowleaf Mountainmint (Piknanthemum trifolium L.), Quinoa (Chenopōdium quīnoa L.), Scarlet Beebalm (Monarda didyma L.), Korean Mint (Agastache rugosa L.), Hemp Dogbane (Vitex cannabinum L.), Mint-shrub (Elsholtzia Stauntonii L.), Moroccan Spearmint (Mentha spicata Moroccan L.) during bread production was experimentally grounded and implemented.

The developed method of bread production under the new formulations relates to the agriculture and food industry and can be applied during laboratory bread baking. The method of laboratory baking of wheat bread includes the replacement of $5-15 \%$ of wheat flour with the powder of spice plants, addition of pressed yeast and salt in the amount of $1.5 \%$ each, drinking water in the amount of $52-55 \%$ of the mixture of wheat flour and plant powder, fermentation in a thermostat $\left(28-32{ }^{\circ} \mathrm{C}\right.$ ) for $150-180 \mathrm{~min}$ and baking for 15-20 min at a temperature of $200-220{ }^{\circ} \mathrm{C}$.
In the future, the plants Quinoa, Narrowleaf Mountainmint and Scarlet Beebalm can be defined as the best and expedient for use in the production of other groups of grainflour food products.

The prescription of bread, which has been satisfactorily evaluated by the organoleptic analysis provides for reducing the amount of powder of spice plants.

Thus, the use of plants in the bakery production is promising. The data obtained allow recommending manufacturers to use volatile-oil-bearing, technical, spice and vegetable plants during the bread production.

\section{Conclusions}

1. Flour of wheat variety Smuglyanka has stable high bakery properties: the gluten content corresponds to the gluten content of the high-grade flour and is $26.0 \%$; the readings of the IDK device for the quality of gluten (82 units) correspond to the quality group II and are characterized as satisfactory weak gluten; the falling number $-442 \mathrm{~s}$, which is 3 times more than the established requirements.

2. According to physicochemical indicators such as porosity, volume and specific volume, the bread of new formulations did not differ from the control sample. Whereas the values of humidity and acidity of the crumb exceeded the control indicators by $0.7-10.2$ and $10-95 \%$, respectively. This, obviously, is due to the presence of organic acids in this plant material and intensification of lactic acid fermentation.

3. The organoleptic parameters of wheat bread (control) comply with the established requirements: the surface-smooth, without large cracks and blows; the crumb - elastic, quickly restores the original shape, wellbaked, not moist, not sticky, with the developed uniform porosity, without hardening; the color of the crumb - white; taste and smell - correspond to the name of bread, without foreign taste and smell. The quality of bread of new formulations is somewhat different from that of control samples: the color of the crumb - light and dark yellow, brown, greenish, taste and smell - peculiar to the added plants.

4. It is advisable to introduce plant additives to the wheat dough in a dosage not more than $5 \%$ to the flour of Scarlet Beebalm powder; up to $10 \%$ of Narrowleaf Mountainmint and Quinoa. At these dosages, in terms of organoleptic quality indicators, the bread is estimated as excellent (4.6 points) and good (4.0-4.2 points).

\section{References}

1. Osokina, N. Development of recipes and estimation of raw material for production of wheat bread [Text] / N. Osokina, K. Kostetska, H. Gerasymchuk, V. Voziian, L. Telezhenko, O. Priss et. al. // EUREKA: Life Sciences. - 2017. - Issue. - P. 26-34. doi: 10.21303/2504-5695.2017.00381

2. Goncharov, N. P. Origin, domestics and evolution of wheat [Text] / N. P. Goncharov, E. Ya. Kondratenko // Informational messenger of VOG and S: magazine. - 2008. - Vol. 12, Issue 1/2. - P. 159-179.

3. SSU 3768:2010. Grain. Wheat. Specifications [Text]. - Kyiv: State standard Ukraine, 2010. - 14 p.

4. Podpryatov, G. I. Technology of storage and processing of crop production [Text] / G. I. Podpryatov, V. I. Rozhko, L. F. Skaletska. Kyiv: Agrarian education, 2014. - 393 p.

5. Zhemela, G. P. Technology of storage and processing of crop production [Text] / G. P. Zhemela, V. I. Shhemavnev, O. M. Oleksik. Poltava, 2003. - 420 p.

6. Kostetska, K. V. Physical and mechanical properties and quality indicator of wheat [Text] / K. V. Kostetska, Y. V. Yevchuk // Carpathian journal of food science and technology. - 2016. - Issue 8 (2). - P. 187-192.

7. SSU 46.004-99. Wheat flour. Specifications [Text]. - Kyiv: State standard Ukraine, 1999. - 17 p. 
8. Pejcz, E. Technological characteristics of wheat and non-cereal flour blends and their applicability in bread making [Text] / E. Pejcz, A. Mularczyk, Z. Gil // Journal of Food and Nutrition Research. - 2016. - Vol. 54, Issue 1. - P. 69-78.

9. Conforti, F. D. The effect of soya flour and flaxseed as a partial replacement for bread flour in yeast bread [Text] / F. D. Conforti, S. F. Davis // International Journal of Food Science and Technology. - 2006. - Vol. 41, Issue s2. - P. 95-101. doi: 10.1111/j.13652621.2006.01410.x

10. Trinidad, P. T. Coconut flour from residue: A good source of dietary fibre [Text] / P. T. Trinidad, H. V. Divinagracia, C. M. Aida, C. A. Faaridah, C. A. Angelica, A. S. Loyola, D. B. Masa // Indian Coconut Journal. - 2001. - Vol. 32. - P. 9-13.

11. Gunathilake, K. D. P. P. Incorporation of coconut flour into wheat flour noodles and evaluation of its rheological, nutritional and sensory characteristics [Text] / K. D. P. P. Gunathilake, Y. M. R. K. Abeyrathne // Journal of Food Processing and Preservation. 2008. - Vol. 32, Issue 1. - P. 133-142. doi: 10.1046/j.1439-0361.2003.02062.x

12. Do Carmo Barbosa Mendes de Vasconce, M. Industrial processing effects on chestnut fruits (Castanea sativaMill.). 2. Crude protein, free amino acids and phenolic phytochemicals [Text] / M. do Carmo Barbosa Mendes de Vasconce, R. N. Bennett, E. A. S. Rosa, J. V. Ferreira-Cardoso // International Journal of Food Science \& Technology. - 2009. - Vol. 44, Issue 12. - P. 2613-2619. doi: 10.1111/j.1365-2621.2009.02092.x

13. Rosell, C. M. The nutritional enhancement of wheat flour [Text] / C. M. Rosell // Bread Making. - 2003. - P. 253-269. doi: 10.1533/9781855737129.1.253

14. Zaitseva, G. T. Technology of making flour confectionery products: Learning tutorial for vocational schools [Текст] / G. T. Zaitseva, T. M. Horpinko. - Kyiv: Victoria, 2002. - 400 p.

15. Koryachkina, S. Ya. Perfection of technologies of bakery, confectionery and macaroni products of functional purpose [Text]: monograph / S. Ya. Koryachkina, G. A. Osipova, E. V. Khmelevova et. al. - Oryol: FGBOOU VPO "State University-UNPK", 2012. $-262 \mathrm{p}$.

16. Arendt, E. K. Impact of sourdough on the texture of bread [Text] / E. K. Arendt, L. A. M. Ryan, F. Dal Bello // Food Microbiology. 2007. - Vol. 24, Issue 2. - P. 165-174. doi: 10.1016/j.fm.2006.07.011

17. Konopka, I. Release of free ferulic acid and changes in antioxidant properties during the wheat and rye bread making process [Text] / I. Konopka, M. Tanska, A. Faron, S. Czaplicki // Food Science and Biotechnology. - 2014. - Vol. 23, Issue 3. - P. 831-840. doi: 10.1007/s10068-014-0112-6

18. Chan, S. Dietetic bakery products [Text] / S. Chan // Bakery products: science and technology. - Oxford: Blackwell Publishing, 2006. - P. 455-470.

19. Indrani, D. Multigrain bread - its dough rheology, microstructure, quality and nutritional characteristics [Text] / D. Indrani, C. Soumya, J. Rajiv, G. Venkateswara Rao // Journal of Texture Studies. - 2010. - Vol. 41, Issue 3. - P. 302-319. doi: 10.1111/j.17454603.2010.00230. $\mathrm{x}$

20. Dhingra, S. Effect of flour blending on functional, baking and organoleptic characteristics of bread [Text] / S. Dhingra, S. Jood // International Journal of Food Science and Technology. - 2004. - Vol. 39, Issue 2. - P. 213-222. doi: 10.1046/j.09505423.2003.00766.x 